\title{
Micromorphological and Chemical Approaches to Understand Changes in Ecological Functions of Metal-Impacted Soils under Various Land Uses
}

\author{
J. A. Acosta, ${ }^{1,2}$ S. Martinez-Martinez, ${ }^{2}$ A. Faz, ${ }^{2}$ J. M. Van Mourik, ${ }^{1}$ and J. M. Arocena ${ }^{3}$ \\ ${ }^{1}$ Institute for Biodiversity and Ecosystem Dynamics, University of Amsterdam, Nieuwe Achtergracht 166, 1018 WV, \\ Amsterdam, The Netherlands \\ ${ }^{2}$ Sustainable Use, Management and Reclamation of Soil and Water Research Group, Technical University of Cartagena, \\ Paseo Alfonso XIII, 52, 30203 Cartagena, Murcia, Spain \\ ${ }^{3}$ Canada Research Chair in Soil and Environmental Sciences, University of Northern British Columbia, Prince George, \\ BC, Canada V2N $4 Z 9$
}

Correspondence should be addressed to J. A. Acosta, ja.acosta@upct.es

Received 28 October 2010; Revised 1 March 2011; Accepted 28 March 2011

Academic Editor: Alessandro Piccolo

Copyright (c) 2011 J. A. Acosta et al. This is an open access article distributed under the Creative Commons Attribution License, which permits unrestricted use, distribution, and reproduction in any medium, provided the original work is properly cited.

\begin{abstract}
We investigated the changes in faunal activities as measures of the ecological functions of soils impacted by potentially toxic metals (PTMs) under urban, industrial, agricultural, and natural uses. Concentrations and distributions of $\mathrm{Zn}, \mathrm{Cd}, \mathrm{Pb}, \mathrm{Cu}, \mathrm{Mn}$, and $\mathrm{Fe}$ were estimated by sequential chemical extractions, while relicts and present faunal activities were studied by micromorphological analyses. Urban and natural lands were contaminated with $\mathrm{Pb}, \mathrm{Cd}$, and $\mathrm{Zn}$. Microarthropods and fungi are observed to be active in the litter decomposition in natural, agricultural and urban lands which indicates that total concentration of PTMs in soils is not a good indicator to evaluate the limitations of PTMs to fauna activity. Metals immobilization on carbonates and Fe/Mn oxides, and fertilizations reduced the negative effects of metals on faunal activity. Micromorphological analyses showed the impacts of metal on soil ecological functions in industrial site, where the surface soils are devoid of any evidence of faunal activity; likely due to high proportion of $\mathrm{Pb}$ and $\mathrm{Zn}$ in organic components. Therefore, the impacts of metals in soil fauna activities, hence ecological functions of soils, are best evaluated by the knowledge of metal partitioning on solid phases in combination with observations of fauna activities using micromorphological techniques.
\end{abstract}

\section{Introduction}

The major anthropogenic sources of potentially toxic metals (PTMs) in soil are urbanization $[1,2]$, industrialization $[3,4]$ and agricultural practices $[5,6]$. In urban areas, atmospheric deposition of particulate matter contributes to the diffuse pollution of surface soils [7]. Atmospheric depositions from industrial plants impact any soils regardless of land use $[8,9]$. Spillage of various liquids and industrial wastes are the principal sources of PTMs accumulation in surface and subsurface soils around industrial areas. In agricultural ecosystems, metals reach the soil from applications of liquid and solid manure or inorganic fertilizers [10, 11].

Mobility of PTMs in soils depends on the retention capacity of the soil and chemical properties of the metal [12].
Metals can bind to soil organic matter (SOM), carbonates, oxides, and hydroxides of $\mathrm{Mn}$ and $\mathrm{Fe}$ or remain in soluble and mobile forms dissolved in the soil solution. Sequential chemical extraction procedures are used to determine the partitioning of metals in various solid phases in soils $[13,14]$.

Although the use of micromorphological analysis to evaluate the role of soil organisms in soil genesis in the last decade has been effective $[15,16]$, its usefulness in understanding the relationships between PTMs and faunal activities to determine the changes in ecological functions of soil systems has not been established. Micromorphological studies were very useful in the understanding of soil structure, aggregates stability as influenced by the activities of soil fauna $[17,18]$. High concentrations of PTMs are known 
to be detrimental to soil fauna activity and eventually may impair ecological functions, thus lead to soil degradation. We postulated that if micromorphological analysis of faunal activities is combined with sequential chemical extraction procedures, the consequences of metal pollution on soil ecological functions could be effectively evaluated.

We tested the above hypothesis in soil around Cartagena city (southeast Spain), where the high demand for land spaces to expand both residential subdivisions and industrial parks created rapid changes to existing land uses. The former land uses around the city were partly industrial and agricultural with nonregulated industrial processes resulting in high rate of metal contamination in soils [19]. Lead, $\mathrm{Zn}, \mathrm{Cd}$, and $\mathrm{Cu}$ are main metal contaminants from old smelter and zinc producing plants in addition to pesticides, fertilizers, and urban wastes [20]. Faz et al. [21] indicated that high concentrations of $\mathrm{Fe}$ and $\mathrm{Mn}$ in the study area are due to industrial activities. Expansion of any European city such as Cartagena must maintain an environmentally "clean" area in accordance with the environmental rules of the European Union (EU). Urban green areas with high ecological qualities are important targets in many recent town architecture planning and development. Ecological restoration of the polluted areas for urban expansion must be based on knowledge of the (former) natural soil systems and their response to anthropogenic perturbations such as metal pollution.

This work presents the results of investigation in various land uses (urban, industrial, agrarian, and natural site) to understand the impacts of anthropogenic activities in ecological functions of soils subjected to continued rapid expansion and urbanization. The main objective was to evaluate the impacts of PTMs pollution on faunal activities by using soil micromorphological analyses coupled with sequential chemical extraction procedures to partition PTMs into various solid phases in soils to understand changes to the ecosystem functions of soils.

\section{Material and Methods}

2.1. Study Area. The study area is located in Cartagena, Murcia (SE Spain) and is characterized by warm temperature with low rainfall and high evapotranspiration rates typical for a Mediterranean type of climate (Figure 1). Large tracts of disturbed and unproductive landscapes in the area were the legacies of extensive mining activities for more than 2500 years. The province has been traditionally associated with agriculture, but industrialization and tourism activities have significantly increased in the last decades. We used the following land use areas in the study.

Industrial Area. The major industrial development during the 1960s resulted to the establishment of several agrochemical, petrochemical and metallurgical installations in this site locally known as "El Hondon". Until two decades ago, factories at El Hondon operated using out-of-date equipment and manufacturing procedures resulting in the generation of vast quantities of industrial wastes. These wastes contain PTMs such as copper, zinc, cadmium, lead, mercury, and arsenic [19] and are stored/disposed over more than $10 \mathrm{~km}^{2}$ of lands in the study site. Many of these disposal areas are potential major sources of soil metal contaminations $[19,21]$.

Agricultural Area. We selected the Campo de Cartagena, one of the largest agricultural areas in Europe covering $\sim 169,800$ hectares, to represent areas dedicated to agricultural activities. The diversion of water through the TajoSegura transfer for irrigation has transformed this area into a highly productive zone for citrus, fruit trees and vegetables (e.g., broccoli, artichoke, melon, lettuce, celery, broad beans, and potatoes). Geologically, it is located in the Betic zone with a very gentle slope and covered by recent continental sediments as surficial ochric horizon and subsurface calcic or petrocalcic horizons. This area represents one of the driest regions of continental Europe and faces many problems associated with agricultural production including scarcity of water, salinity, soil erosion, and desertification.

Urban Area. The selected study site is a city park with an estimated population density of 376 inhabitant $/ \mathrm{km}^{2}$ in 2008 . Soils in this study site are man-made from the additions of natural soil to support the growth of grasses for several decades. These soils are subject to metal emissions from traffic (such as $\mathrm{Cd}$ and $\mathrm{Pb}$ ), irrigation water and extensive inorganic fertilizations to maintain the vegetation (e.g., grasses and flowers) in the park.

Natural Area. This area is located in a small hill used for recreational activities such as cycling, trekking and walking. Plant cover is low $(<20 \%)$ and is mainly composed by shrubs such as Thymus hyemalis and Rosmarius officinalis. No specific management of plant communities is carried out. The dominant soil parent material is composed of quaternary colluvial deposits.

2.2. Soil Description and Sampling. Soil profiles from each area were selected and macromorphologically described following the FAO system [22] and classified using Word Reference Base system [23] (Table 1). The taxonomic classification of each pedon and the associated soil horizons (and depth) in each study sites are the following:

(i) industrial area: calcaric Fluvisol-A $(0-20 \mathrm{~cm}), \mathrm{C} 1$ $(20-35 \mathrm{~cm})$ and $\mathrm{C} 2(35-66 \mathrm{~cm})$,

(ii) urban area: urbic Antropic Regosol-A $(0-20 \mathrm{~cm})$ and $\mathrm{C} 2(>35 \mathrm{~cm})$,

(iii) natural area: haplic Calcisol-A $(0-20 \mathrm{~cm})$ and $\mathrm{C} 1$ $(>20 \mathrm{~cm})$,

(iv) agricultural area: haplic Calcisol- $\mathrm{A}(0-20 \mathrm{~cm})$ and C1 $(>20 \mathrm{~cm})$.

From each horizon, an undisturbed sample was collected for soil micromorphological analyses using Kubiena box. In addition, bulk sample was taken for chemical analysis including the sequential chemical extractions to partition the 


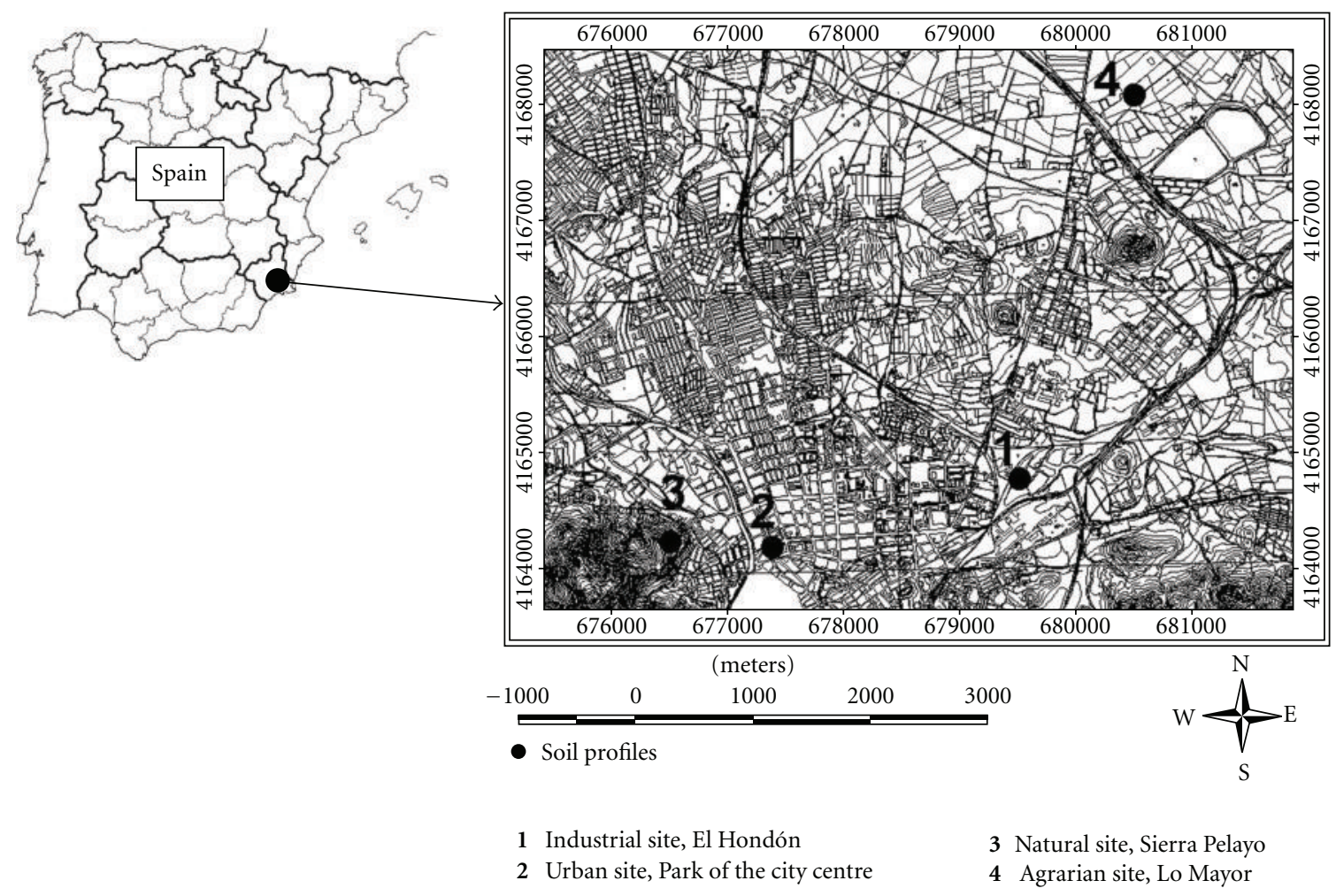

FIGURE 1: Location of the four selected sites around Cartagena, SE Spain.

distribution of metals in various solid phases in soils. Plant material such as stalks, leaves, and roots were collected from each study site. Soil and plants samples were sealed with polythene bags and transported into laboratory for chemical analyses.

2.3. Analytical Methods. Soil samples were air dried for 48 hours at $45^{\circ} \mathrm{C}$ and sieved to pass $2-\mathrm{mm}$ sieve. A subsample of each sample was finely ground in an agate mortar and stored in covered bottles. Plant materials were washed with deionized water and separated into roots, stems, and leaves. The samples were oven dried at $70^{\circ} \mathrm{C}$ for 48 hours and ground for metal analyses.

Selected soil properties relevant to the mobility and bioavailability of PTMs in soils were determined. Soil pH was measured in water and $1 \mathrm{M} \mathrm{CaCl}$ using a $1: 2.5$ soil/solution ratio [24] and electrical conductivity (EC) was determined in saturation paste extract. Calcium carbonate was determined by the Wesemael method [25], while organic carbon (OC) was measured using the wet oxidation method [26]. Granulometric analysis was carried out by sieving (sand) and sedimentation and extraction with a Robinson pipette (clay and silt). Cation exchange capacity (CEC) was estimated by the method proposed by Rhoades [27].

Pseudototal heavy metal contents were analyzed by microwave extraction using the aqua regia procedure consisting of soil sample digestion in a $3: 1\left(\mathrm{HNO}_{3}: \mathrm{HCl}\right)$ solution [28]. The soil samples were also sequentially extracted according to Tessier et al. [13] and Bettinelli et al. [28]. A brief description of each fraction is described below.

Fraction 1 (F1). $\mathrm{MgCl}_{2}$ Extractable. The sample was extracted at room temperature for $1 \mathrm{~h}$ with $8 \mathrm{~mL}$ of $1 \mathrm{M}$ $\mathrm{MgCl}_{2}$ at $\mathrm{pH} 7.0$ with continuous agitation.

Fraction 2 (F2). NaOAc Extractable. The residue from F1 was leached at room temperature with $8 \mathrm{~mL}$ of $1 \mathrm{M} \mathrm{NaOAc}$ adjusted to $\mathrm{pH} 5.0$ with acetic acid (HOAc). Continuous agitation was maintained for $5 \mathrm{~h}$.

Fraction 3 (F3). Oxidizable. The residue from $\mathrm{F} 2$ was extracted with $3 \mathrm{~mL}$ of $0.02 \mathrm{M} \mathrm{HNO}_{3}$ and $5 \mathrm{~mL}$ of $30 \% \mathrm{H}_{2} \mathrm{O}_{2}$ (adjusted to $\mathrm{pH} 2$ with $\mathrm{HNO}_{3}$ ). This mixture was heated to $85^{\circ} \mathrm{C}$ for $2 \mathrm{~h}$ with slow continuous agitation. A second $3 \mathrm{~mL}$ aliquot of $30 \% \mathrm{H}_{2} \mathrm{O}_{2}$ ( $\mathrm{pH} 2$ with $\mathrm{HNO}_{3}$ ) was added and the mixture heated to $85^{\circ} \mathrm{C}$ for $3 \mathrm{~h}$ with slow continuous agitation. After cooling, $5 \mathrm{~mL} \mathrm{HNO}_{3}$ was added and the sample was continuously agitated for $30 \mathrm{~min}$.

Fraction 4 (F4). Reducible and Residual. The residue fromF3 was digested using aqua regia.

Cadmium, $\mathrm{Cu}, \mathrm{Fe}, \mathrm{Mn}, \mathrm{Pb}$, and $\mathrm{Zn}$ in soil digests and plant extracts were analyzed by ICP-OES (Perkin Elmer Optima 3000 XL, AS 90). These metals were selected because of their association with industrial, urban, and agrarian activities common in the study areas. 
TABLE 1: Macromorphological description of selected soil profile following FAO system (FAO-ISRIC, 2006).

\begin{tabular}{|c|c|c|c|c|c|c|}
\hline Sites & Horizon & Texture & Structure & Gravels/stones & Pores & Roots \\
\hline \multirow{3}{*}{$\begin{array}{l}\text { Industrial (Calcaric } \\
\text { Fluvisol) }\end{array}$} & A $(0-20 \mathrm{~cm})$ & Silt loam & $\begin{array}{l}\text { Subangular blocky } \\
\text { structure, fine, and } \\
\text { medium strong }\end{array}$ & $\begin{array}{l}\text { Few gravels and few } \\
\text { subrounded stones }\end{array}$ & $\begin{array}{l}\text { Common, fine, and } \\
\text { few medium and } \\
\text { coarse pores and } \\
\text { medium porosity }\end{array}$ & Few fine roots \\
\hline & $\mathrm{C} 1(20-35 \mathrm{~cm})$ & Silt loam & $\begin{array}{l}\text { Subangular blocky } \\
\text { structure, very fine, } \\
\text { and weak }\end{array}$ & $\begin{array}{l}\text { Few angular to } \\
\text { subrounded gravels }\end{array}$ & $\begin{array}{l}\text { Many very fine pores } \\
\text { and low porosity }\end{array}$ & $\begin{array}{l}\text { Very few fine } \\
\text { roots }\end{array}$ \\
\hline & $\mathrm{C} 2(35-66 \mathrm{~cm})$ & Silt loam & Massive structure & $\begin{array}{l}\text { Very few gravels and } \\
\text { few stones }\end{array}$ & $\begin{array}{l}\text { Few very fine pores } \\
\text { and low porosity }\end{array}$ & No roots \\
\hline \multirow[t]{2}{*}{$\begin{array}{l}\text { Agricultural (Haplic } \\
\text { Calcisol) }\end{array}$} & A $(0-20 \mathrm{~cm})$ & Clay loam & $\begin{array}{l}\text { Granular structure, } \\
\text { very fine to fine, } \\
\text { and weak }\end{array}$ & Few gravels & $\begin{array}{l}\text { Common, fine, and } \\
\text { medium and few } \\
\text { coarse pores and } \\
\text { medium porosity }\end{array}$ & $\begin{array}{l}\text { Many fine and } \\
\text { medium and few } \\
\text { coarse roots }\end{array}$ \\
\hline & $\mathrm{C}(>20 \mathrm{~cm})$ & Clay loam & Massive structure & No gravels and stones & $\begin{array}{l}\text { Common, fine, and } \\
\text { medium pores and } \\
\text { medium porosity }\end{array}$ & $\begin{array}{l}\text { Few fine and } \\
\text { medium and } \\
\text { coarse roots }\end{array}$ \\
\hline \multirow[t]{2}{*}{$\begin{array}{l}\text { Urban (Technic } \\
\text { Regosol) }\end{array}$} & $\mathrm{A}(0-20 \mathrm{~cm})$ & Loam & $\begin{array}{l}\text { Subangular blocky } \\
\text { structure, fine, and } \\
\text { weak }\end{array}$ & No gravels and stones & $\begin{array}{l}\text { Very common, fine, } \\
\text { and medium and } \\
\text { coarse pores and high } \\
\text { porosity }\end{array}$ & $\begin{array}{l}\text { Many fine and } \\
\text { medium and } \\
\text { coarse roots }\end{array}$ \\
\hline & $\mathrm{C}(>20 \mathrm{~cm})$ & Loam & Massive structure & No gravels and stones & $\begin{array}{l}\text { Few fine, and very few } \\
\text { medium pores and } \\
\text { low porosity }\end{array}$ & $\begin{array}{l}\text { Very few fine } \\
\text { roots }\end{array}$ \\
\hline \multirow[t]{2}{*}{$\begin{array}{l}\text { Natural (Haplic } \\
\text { Calcisol) }\end{array}$} & $\mathrm{A}(0-20 \mathrm{~cm})$ & $\begin{array}{l}\text { Silty clay } \\
\text { loam }\end{array}$ & $\begin{array}{l}\text { Granular structure, } \\
\text { fine to medium } \\
\text { and hard }\end{array}$ & $\begin{array}{l}\text { Few angular gravel } \\
\text { and stones }\end{array}$ & $\begin{array}{l}\text { Common fine and } \\
\text { medium and coarse } \\
\text { pores and high } \\
\text { porosity }\end{array}$ & $\begin{array}{l}\text { Common fine } \\
\text { and medium and } \\
\text { few coarse roots }\end{array}$ \\
\hline & $\mathrm{C}(>20 \mathrm{~cm})$ & Silty clay & Massive structure & $\begin{array}{l}\text { Few angular gravel } \\
\text { and stones }\end{array}$ & $\begin{array}{l}\text { Few fine and medium } \\
\text { pores and medium to } \\
\text { low porosity }\end{array}$ & $\begin{array}{l}\text { Common fine } \\
\text { and few medium } \\
\text { and very few } \\
\text { coarse roots }\end{array}$ \\
\hline
\end{tabular}

Reference soils (SO-3 and SO-4) from the Canadian Certified Reference Materials Project [29] and reagent blanks were used as the quality control samples during the analyses. We obtained recoveries for the pseudototal potential toxic metals extraction of $95 \%-115 \%$ for Cd, $81 \%-98 \%$ for $\mathrm{Cu}$, 90\%-99\% for $\mathrm{Mn}, 91 \%-99 \%$ for $\mathrm{Fe}, 93 \%-97 \%$ for $\mathrm{Pb}$ and $101 \%-115 \%$ for $\mathrm{Zn}$. When we the sequential extraction techniques was used in reference soils, the percentages of recoveries, calculated comparing the certificated concentrations and the sum of the concentrations for each solid phase, were: $109 \%-117 \%$ for $\mathrm{Cd}, 98 \%-110 \%$ for $\mathrm{Cu}, 97 \%-104 \%$ for $\mathrm{Mn}, 89 \%-99$ for $\mathrm{Fe}, 102 \%-108 \%$ for $\mathrm{Pb}$ and $99 \%-111 \%$ for $\mathrm{Zn}$.

The soil matrix structure and composition were observed in soil thin sections using a petrographic under a magnification factor of $60 x$. Features of interests such as excrements of arthropods were counted in grid formed by a $5 \times 5 \mathrm{~mm}$ area. Detailed information about microbial activity and fabric of aggregates was obtained using the magnification factors of $160 x$ and $400 x$ [30, 31]. We related the following micromorphological features to the activities of soil fauna.

(i) Slightly decomposed soil organic matter (SOM) are materials where the structures of the constituents from which this OM comes are recognizable.

(ii) Moderately decomposed SOM are materials where the structures are partially observable due to partial decomposition.

(iii) Intensively decomposed SOM are organic remains where original structures are not observable due to an intense decomposition.

(iv) Insect remains are any recognizable part of soil fauna such as bodies, legs, and antennas of insects.

(v) Fungal remains are exemplified by fungal hyphae and mycelium. 
(vi) Recent excrements are identified by original shape, without significant alterations, of faunal fecal droppingd.

(vii) Ancient excrements are altered excrement indicated by loss of its initial shape and structure.

(viii) Voids are areas without the presence of any recognizable components.

(ix) Free mineral grains are minerals without any association with other component.

(x) Course mineral components in aggregates are coarse minerals within aggregates.

(xi) Fine mineral components in aggregates are fine minerals within aggregates.

2.4. Assessment of the Degree of Potentially Toxic Metal Accumulations. We compared the PTMs contents in soil samples with the the local background concentration proposed by Martínez-Sánchez and Pérez-Sirvent [32] to assess any accumulation of metals in the study areas. These authors [32] collected 215 samples located $\sim 1 \mathrm{~km}$ away from many industrial, mining, and urban areas in the entire Murcia Province to assess areas with minimum anthropogenic impacts. The pseudototal PTMs and mineralogical composition were grouped into five classes based on parent material to determine the background metal contents in each study site. The local background for each element was equivalent to calculated median value for each parent material.

2.5. Statistical Analysis. Correlation matrix (CM) and cluster analysis (CA) were used to identify potential sources of metal enrichments [33]. The Pearson correlation coefficient $(r)$ was used to measure the relationship between two quantitative variables (metals), while CA was used to elucidate the latent relationships between metals, and was undertaken according to the average linkage method. Results were shown in a dendrogram where steps in the hierarchical clustering solution and values of the distances between clusters (Pearson correlation distance) were represented. Statistical calculations were performed by using SPSS 15.0 for Windows [34].

\section{Results and Discussion}

3.1. Soil Properties and Characteristics. Soil $\mathrm{pH}$ values are alkaline in the agricultural soils and moderately alkaline in the industrial areas. These high $\mathrm{pH}$ values were due to the presence of carbonates in the $\mathrm{C}$ horizons of the study sites (Table 2). The calcium carbonate accumulation in soil profiles is a commonly occurring soil process in arid and semi-arid regions similar to the study areas [35].

The soils under agriculture and natural uses are not saline while soils in the urban and in industrial areas, where the anthropogenic influence is high are lightly or moderately saline. The OC contents are very high in the surface horizons of the urban and natural areas and very low in the industrial sites. The $N$ levels range between 0.02 and $0.24 \%$ and

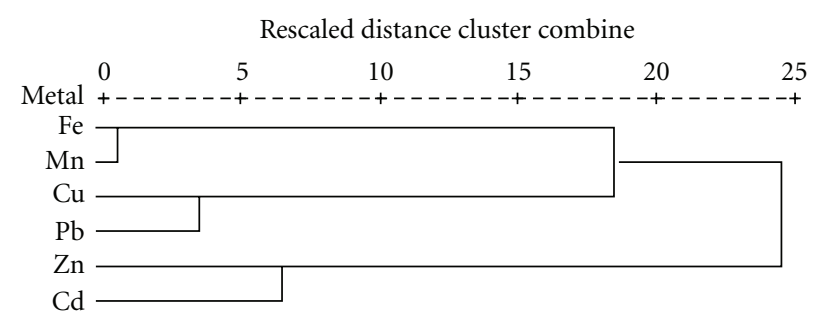

Figure 2: Dendogram of metals for all soil uses.

are highly associated with SOM content [36]. The $C / N$ ratios range from 10 to 15 indicating a moderate degree of humification that is conducive to the development of a mull humus form. The CEC is moderately low in most of the soil horizons [37]; however, urban and agricultural soils have distinctly higher CEC than industrial soils. The majority of the horizons studied have fine textures, ranging from calcaric loam to calcaric silty clay. The clay and silt contents are $>60 \%$ and silt contents are higher than clay.

3.2. Metals Pollution and Its Possible Sources. Pseudototal metal contents revealed high concentrations of $\mathrm{Cd}, \mathrm{Pb}$ and $\mathrm{Zn}$ in the $\mathrm{A}$ and $\mathrm{C}$ horizons of soils in most study sites (Table 2) in comparison with the local background. These elevated values of PTMs are indicative that metal accumulations are not restricted to topsoil but also affected the subsurface soils of some profiles. We also believe that extensive anthropogenic activities are a important source of metals in soils collected under various land uses in the study areas.

Figure 2 displays three main groups in the hierarchical dendogram obtained by cluster analysis. The first group is composed of $\mathrm{Mn}$ and $\mathrm{Fe}$, while the second one includes $\mathrm{Pb}$ and $\mathrm{Cu}$, and finally, the third cluster is formed by $\mathrm{Zn}$ and $\mathrm{Cd}$. The high relationship between metals in each group may indicate similar provenance. In other words, CA suggests at least three possible different sources of PTMs in the study area. This claim is supported by the significant $(P<.01)$ correlations coefficients $(r)$ calculated among these metals (Table 3): $\mathrm{Mn}-\mathrm{Fe}(r=0.92)$; $\mathrm{Cu}-\mathrm{Pb}(r=0.76)$; $\mathrm{Cd}-\mathrm{Zn}$ $(r=0.62)$.

Soils collected from the industrial site (calcaric fluvisol) show the highest $\mathrm{Zn}$ and $\mathrm{Cd}$ concentrations in the A horizon (1,002 and $4.1 \mathrm{mg} \mathrm{kg}^{-1}$ soil, resp.). We measured the lowest values of $\mathrm{Pb}$ and $\mathrm{Cu}$ in the same pedon. Emissions from industrial processes from a $\mathrm{Zn}$ producing and old bicalcic phosphate fertilizer factories maybe responsible for the elevated concentrations of $\mathrm{Zn}$ and $\mathrm{Cd}$ in the in the study areas $[20,38]$.

The urban site (technic regosol) has high concentrations of $\mathrm{Fe}$ and accumulations of $\mathrm{Zn}, \mathrm{Pb}$, and $\mathrm{Cd}$. These observations coupled with the abrupt decreases in $\mathrm{Cd}$ and $\mathrm{Zn}$ contents in the $\mathrm{C}$ horizon may reflect the contamination of surface soil by abrasion of tires and brake pads from the intense vehicular traffic $[39,40]$. The presence of the highest concentration of $\mathrm{Pb}$ in this land use suggests that traffic is the main source of this PTMs in the study areas. 
TABLE 2: Selected soil properties and pseudototal metals concentration of the A and C horizons of soils under various land uses in Cartagena (SE Spain).

\begin{tabular}{|c|c|c|c|c|c|c|c|c|c|c|}
\hline \multirow{2}{*}{$\begin{array}{l}\text { Sites } \\
\text { horizons }\end{array}$} & \multicolumn{3}{|c|}{ Industrial } & \multicolumn{2}{|c|}{ Urban } & \multicolumn{2}{|c|}{ Natural } & \multicolumn{2}{|c|}{ Agricultural } & \multirow{2}{*}{$\begin{array}{l}\text { Local } \\
\text { background }\end{array}$} \\
\hline & $\mathrm{A}$ & $\mathrm{C} 1$ & $\mathrm{C} 2$ & A & $\mathrm{C}$ & $\mathrm{A}$ & $\mathrm{C}$ & A & $\mathrm{C}$ & \\
\hline $\mathrm{pH} \mathrm{H} \mathrm{H}_{2} \mathrm{O}$ & 7.5 & 7.6 & 7.5 & 7.2 & 7.5 & 7.1 & 7.7 & 7.9 & 7.9 & \\
\hline $\mathrm{pH} \mathrm{CaCl} 2$ & 7.1 & 7.4 & 7.3 & 7 & 7.3 & 6.7 & 7.1 & 7.1 & 7.1 & \\
\hline E.C. $(\mathrm{ds} / \mathrm{m})$ & 2.7 & 5.7 & 4.3 & 2.7 & 2.3 & 0.8 & 0.3 & 0.5 & 0.5 & \\
\hline $\mathrm{CaCO}_{3}(\%)$ & 32.7 & 43.6 & 28.1 & 23.7 & 21.9 & 60.6 & 68.6 & 24.8 & 29.7 & \\
\hline O.C. (\%) & 0.61 & 0.27 & 0.56 & 3.13 & 0.88 & 2.64 & 1.15 & 1.34 & 1.07 & \\
\hline T.N. (\%) & 0.05 & 0.02 & 0.05 & 0.24 & 0.06 & 0.21 & 0.1 & 0.11 & 0.1 & \\
\hline$C / N$ & 12.2 & 13.5 & 11.2 & 13.1 & 14.6 & 12.6 & 11.5 & 12.2 & 10.1 & \\
\hline $\begin{array}{l}\text { CEC } \\
\left(\mathrm{cmokg}^{-1}\right)\end{array}$ & 7.9 & 7.6 & 11.2 & 13.8 & 7.7 & 6.9 & 8.2 & 12.5 & 14.3 & \\
\hline Clay (\%) & 11.8 & 24.3 & 14.1 & 17.3 & 11.6 & 39.4 & 47.1 & 29 & 25.6 & \\
\hline Silt (\%) & 61.3 & 55.2 & 57.2 & 43.2 & 40.6 & 49.5 & 40.8 & 50.7 & 55 & \\
\hline $\mathrm{Fe}\left(\mathrm{mg} \mathrm{kg}^{-1}\right)$ & 20831 & 19696 & 19195 & 26444 & 25080 & 14999 & 12554 & 24827 & 24520 & - \\
\hline $\operatorname{Mn}\left(\mathrm{mg} \mathrm{kg}^{-1}\right)$ & 338 & 319 & 244 & 449 & 396 & 283 & 221 & 450 & 444 & - \\
\hline $\mathrm{Zn}\left(\mathrm{mg} \mathrm{kg}^{-1}\right)$ & 1002 & 796 & 65 & 523 & 163 & 212 & 143 & 342 & 331 & 41.4 \\
\hline $\mathrm{Cu}\left(\mathrm{mg} \mathrm{kg}^{-1}\right)$ & 28.1 & 19.6 & 17.1 & 48 & 46.9 & 15.1 & 13.9 & 23.6 & 17.9 & 12.6 \\
\hline $\mathrm{Pb}\left(\mathrm{mg} \mathrm{kg}^{-1}\right)$ & 58.2 & 103.2 & 8.5 & 411.1 & 400.7 & 248.8 & 179.8 & 128.3 & 88.1 & 9.3 \\
\hline $\mathrm{Cd}\left(\mathrm{mg} \mathrm{kg}^{-1}\right)$ & 4.1 & 2.6 & 0.2 & 3 & 0.5 & 3.4 & 0.8 & 3.7 & 3.8 & 0.32 \\
\hline
\end{tabular}

E.C.: electrical conductivity; O.C.: organic carbon; T.N.: total nitrogen; C.E.C.: cation exchange capacity.

TABLE 3: Correlation coefficient matrix among metals.

\begin{tabular}{lccccc}
\hline & $\mathrm{Fe}$ & $\mathrm{Mn}$ & $\mathrm{Zn}$ & $\mathrm{Cu}$ & $\mathrm{Cb}$ \\
\hline $\mathrm{Fe}$ & 1.00 & & & & \\
$\mathrm{Mn}$ & $\mathbf{0 . 9 2 ^ { * * }}$ & 1.00 & & & \\
$\mathrm{Zn}$ & 0.21 & 0.22 & 1.00 & & \\
$\mathrm{Cu}$ & $\mathbf{0 . 7 1 ^ { * * }}$ & $\mathbf{0 . 5 9 ^ { * }}$ & 0.16 & 1.00 & \\
$\mathrm{~Pb}$ & 0.30 & 0.35 & -0.20 & $\mathbf{0 . 7 6 ^ { * * }}$ & \\
$\mathrm{Cd}$ & 0.28 & $\mathbf{0 . 5 3 ^ { * }}$ & $\mathbf{0 . 6 2 ^ { * * }}$ & -0.06 & -0.14 \\
${ }^{* *} P<.01{ }^{*} P<.05$ & & & & & 1.00 \\
\hline
\end{tabular}

${ }^{* *} P<.01,{ }^{*} P<.05$.

The natural site (haplic calcisol) has the lowest concentrations of Fe and Mn similar to the background level. However, the $\mathrm{A}$ and $\mathrm{C}$ horizons are contaminated with $\mathrm{Zn}$, $\mathrm{Pb}$, and $\mathrm{Cd}$ when compared with the local background. A previous study [20] revealed that the direction of the dominant wind directions in the area [41] and the location of the mountains in relation to the location of the city park contributed to the significant wind deposition of particles with PTMs.

We observed that soils under agricultural use (haplic calcisol) have higher concentrations of metals than the local background. The addition of fertilizers such as phosphates and pesticides/herbicides in agriculture practices [42] and the incorporation of sewage sludge are likely responsible for the accumulation of metals in agrarian soils in the study sites.

3.3. Patitioning of Potential Toxic Metals. Results of correlation analysis indicate that carbonates has a negative correlation with the oxidizable and reducible/residual phases for most metals which may suggests that increases in carbonate contents decreases the amounts metal bound to the oxidizable and reducible/residual solid phases (Table 4). It is likely that carbonates act as effective sinks for metals thus, reducing the concentrations of available metals to bind with other solid phases.

3.4. Micromorphological Features, Potential Toxic Metals and Their Significance to the Ecosystem Function of Soils. One of the major indicators for a properly-functioning soilecological system is the different stage of decomposition of SOM. In soils with neutral to alkaline $\mathrm{pH}$, microbial organisms, arthropods and earthworms are involved in litter decomposition and production of SOM. However, elevated levels of metals are toxic to microorganisms and might reduce the diversity of soil microbial community [43]. Wang et al. [44] found a negative correlation between soil microbial activity, community diversity, and extractable and pseudototal PTMs.

The distributions of organic and inorganic components in four pedons were shown in Table 5. In soils under natural 
TABLE 4: Correlation coefficient matrix among soil properties and metals in soil solid phases.

\begin{tabular}{clcccccccc}
\hline & & $\mathrm{pH}$ & $\mathrm{EC}$ & $\mathrm{CaCO}_{3}$ & $\mathrm{OC}$ & $\mathrm{CEC}$ & Clay & Silt & Sand \\
\hline \multirow{4}{*}{$\mathrm{Fe}$} & MgCl extractable & -0.09 & $\mathbf{0 . 6 1}$ & -0.08 & -0.54 & -0.42 & -0.48 & $\mathbf{0 . 6 9}$ & 0.07 \\
& NaOAc extractable & 0.00 & 0.21 & -0.18 & -0.49 & $-\mathbf{0 . 6 1}$ & -0.43 & -0.13 & 0.52 \\
& Oxidizable & -0.07 & 0.39 & $-\mathbf{0 . 6 9}$ & -0.33 & 0.15 & $-\mathbf{0 . 8 5}$ & 0.33 & $\mathbf{0 . 6 7}$ \\
& Reducible/residual & 0.29 & 0.03 & $-\mathbf{0 . 8 8}$ & 0.03 & 0.58 & -0.58 & -0.03 & $\mathbf{0 . 6 1}$ \\
\hline \multirow{4}{*}{$\mathrm{Mn}$} & MgCl extractable & -0.20 & 0.49 & $-\mathbf{0 . 8 2}$ & 0.05 & 0.45 & $-\mathbf{0 . 8 9}$ & 0.19 & $\mathbf{0 . 8 0}$ \\
& NaOAc extractable & -0.41 & -0.47 & -0.28 & $\mathbf{0 . 7 6}$ & 0.39 & -0.16 & -0.33 & 0.36 \\
& Oxidizable & $\mathbf{0 . 7 8}$ & -0.15 & $-\mathbf{0 . 6 4}$ & -0.48 & 0.53 & -0.35 & 0.38 & 0.13 \\
& Reducible/residual & 0.04 & 0.07 & -0.58 & 0.37 & 0.52 & -0.31 & -0.17 & 0.42 \\
\hline \multirow{4}{*}{$\mathrm{Zn}$} & MgCl extractable & -0.25 & 0.54 & -0.33 & -0.23 & 0.05 & $-\mathbf{0 . 6 3}$ & 0.52 & 0.33 \\
& NaOAc extractable & -0.11 & -0.11 & -0.20 & 0.10 & 0.04 & -0.33 & 0.34 & 0.13 \\
& Oxidizable & -0.01 & -0.02 & -0.28 & -0.11 & -0.03 & -0.44 & 0.49 & 0.14 \\
& Reducible/residual & 0 & $\mathbf{0 . 6 6}$ & 0.08 & -0.25 & -0.24 & -0.06 & 0.29 & -0.12 \\
\hline \multirow{4}{*}{$\mathrm{Cu}$} & MgCl extractable & -0.59 & -0.14 & -0.29 & $\mathbf{0 . 7 9}$ & 0.16 & -0.16 & $-\mathbf{0 . 6 2}$ & 0.54 \\
& NaOAc extractable & $-\mathbf{0 . 6 4}$ & 0.39 & -0.36 & 0.33 & -0.10 & -0.59 & -0.24 & $\mathbf{0 . 7 5}$ \\
& Oxidizable & -0.06 & -0.08 & $-\mathbf{0 . 7 3}$ & 0.40 & 0.55 & -0.52 & -0.37 & $\mathbf{0 . 7 6}$ \\
& Reducible/residual & 0.05 & -0.18 & -0.53 & 0.11 & 0.15 & -0.33 & $-\mathbf{0 . 6 3}$ & $\mathbf{0 . 7 2}$ \\
\hline \multirow{4}{*}{$\mathrm{Pb}$} & MgCl extractable & - & - & - & - & - & - & - & - \\
& NaOAc extractable & -0.51 & -0.10 & -0.27 & $\mathbf{0 . 6 5}$ & 0.11 & -0.19 & $-\mathbf{0 . 7 7}$ & $\mathbf{0 . 6 7}$ \\
& Oxidizable & -0.05 & $-\mathbf{0 . 6 8}$ & 0.03 & $\mathbf{0 . 7 8}$ & 0.42 & 0.42 & $-\mathbf{0 . 6 8}$ & -0.01 \\
& Reducible/residual & -0.45 & -0.28 & 0.29 & 0.59 & -0.30 & 0.32 & $-\mathbf{0 . 7 5}$ & 0.14 \\
\hline
\end{tabular}

and agricultural land uses, the porosity is significantly higher than urban and industrial areas. Earthworms and microarthropods are known to increase soil void space, particularly large voids, especially when the activity of the fauna is stimulated by the addition of $N$ fertilizer [45]. The use of $N$ fertilizers in agricultural lands favours faunal activity, thus increases soil porosity (Table 5). In addition, intensively decomposed SOM and recent features of microbiological activity observed in this soil indicated that high metal contents do not prevent activities of fungi and microarthropods (Figure 3). This can be due to the complexation of $\mathrm{Pb}, \mathrm{Cu}$, and $\mathrm{Zn}$ with some soil constituents (e.g., carbonates) which make them less available to microbial activities. Unavailability of chelated metals may also explain the lower amounts of metals (except $\mathrm{Fe}$ ) in plant materials on this study site compared to other areas (e.g., industrial) (Table 6). Furthermore, we think that the application of inorganic and organic fertilizers in agricultural areas enhance microbiological activities and prevent the toxic effect of metals to maintain soil ecological functions.

In the natural area, although pseudototal $\mathrm{Pb}$ and $\mathrm{Zn}$ concentrations are high, intensively decomposition of SOM was observed in the $\mathrm{A}$ and $\mathrm{C}$ horizons where $>5 \%$ (Figure $3(\mathrm{a})$ ) of areas in thin section showing that microbiological activities are actively taking place (Figure 3(b)). This may be due to immobilization of most metals as carbonates, reducible and residual phase, and only low amount of $\mathrm{Pb}$ and $\mathrm{Zn}$ is bound to oxidizable phase, and, therefore, do not significantly affect the activities of the soil fauna (Figure 4 and Table 7). Metal concentrations in plant material on this profile were the lowest except $\mathrm{Fe}$ (Table 6) indicating that fauna activities in the presence of metals can decompose SOM without any toxic effect.

Recent excrements and fungal remains are observed in the A horizon in urban soils indicative for active populations of earthworms, microarthropods and fungi in this land use (Figures 3(c) and 3(d)). We think that faunal activities are supported by the addition of fertilizers, the use of irrigation water and the presence of grass around the year. In spite of this, moderately decomposed SOM in the A horizon shows that the speed of SOM decomposition is lower in urban than in agricultural and natural land uses. This observation may be a consequence of the combination of two factors: the presence of cover vegetation all year round and the actual management of City Park, where the soil is irrigated daily to prevent a high rate of humification and mineralization, and the presence of high concentrations of $\mathrm{Zn}$ and $\mathrm{Pb}$ in plant material (Table 6).

High pseudototal $\mathrm{Pb}, \mathrm{Cd}$, and $\mathrm{Zn}$ contents in soils could lightly reduce faunal activity [46, 47]. However, in the study areas, large proportions of the pseudototal PTMs are in unavailable forms, strongly bound to carbonates and reducible/residual solid phases (Figure 4). It is expected that fungi and arthropods activities are not seriously affected in this profile as observed in micromorphological examinations (Figures 3(e) and 3(f)). In arid zones, the presence of high amount of carbonates favours metals immobilization by adsorption or nucleation on the mineral surfaces. It is known that high $\mathrm{pH}$ causes precipitation of metals as hydroxides [12]. 


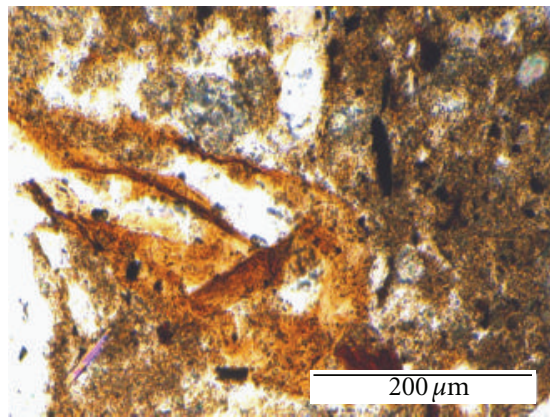

(a)

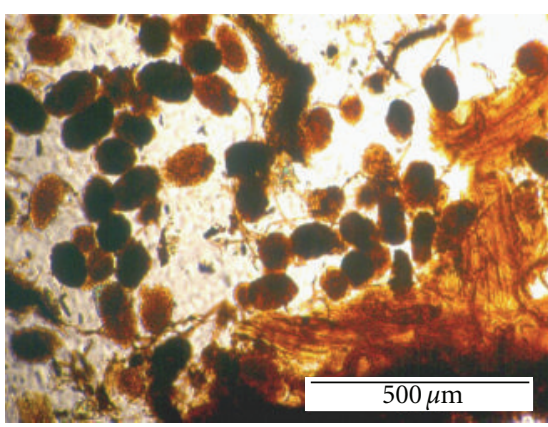

(d)



(b)

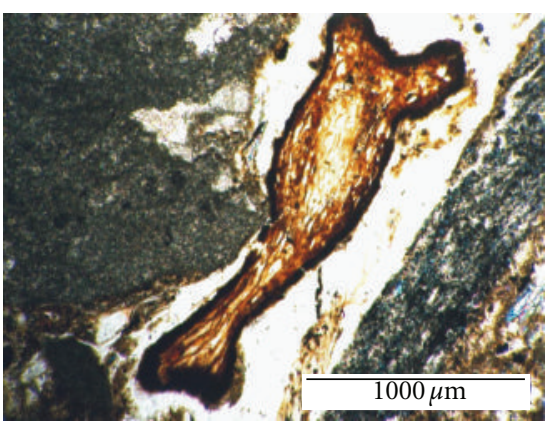

(e)

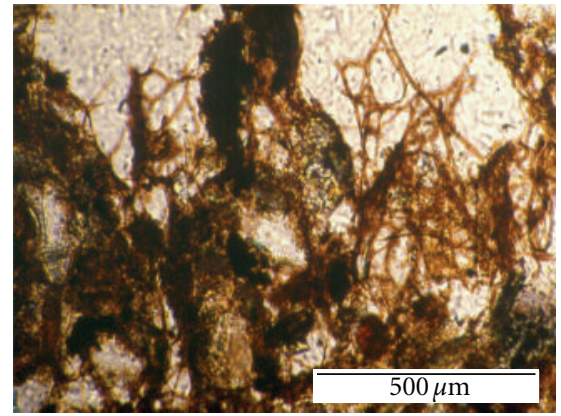

(c)

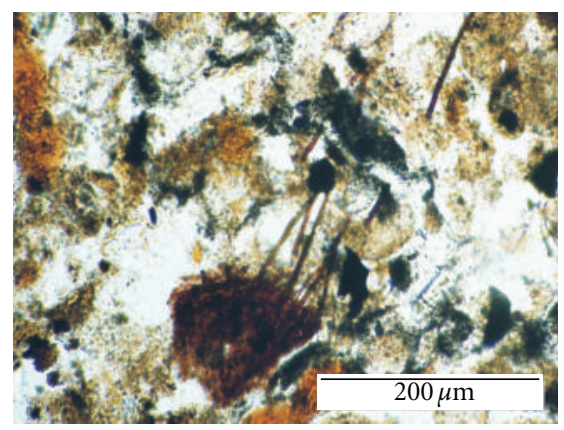

(f)

Figure 3: (a) Intensively decomposed soil organic matter from the C1 horizon in natural site; (b) Excrements of micro arthropods inside a litter fragment in an early state of decomposition from the A horizon in natural site; (c) Fugal hyphae penetrating into organic remains from A horizon in urban site; (d) Recent excrements of arthropods from the A horizon in urban soil; (e) Slightly decomposed soil organic matter from the A horizon in industrial site; (f) Fugal hyphae penetrating into fossilized remains of soil organic from the C2 horizon in industrial site.

TABLE 5: Distribution (\%) of organic and inorganic components in thin sections of the soil horizons under various land uses in Cartagena (SE Spain).

\begin{tabular}{|c|c|c|c|c|c|c|c|c|c|}
\hline & \multicolumn{3}{|c|}{ Industrial } & \multicolumn{2}{|c|}{ Urban } & \multicolumn{2}{|c|}{ Natural } & \multicolumn{2}{|c|}{ Agricultural } \\
\hline & A & $\mathrm{C} 1$ & $\mathrm{C} 2$ & A & $\mathrm{C} 1$ & A & $\mathrm{C} 1$ & A & $\mathrm{C} 1$ \\
\hline Slightly decomposed organic matter & 4 & 0 & 0 & 0 & 0 & 0 & 0 & 0 & 0 \\
\hline $\begin{array}{l}\text { Moderately decomposed organic } \\
\text { matter }\end{array}$ & 1 & 0 & 0 & 4.5 & 1.8 & 0 & 0 & 0 & 0 \\
\hline $\begin{array}{l}\text { Intensively decomposed organic } \\
\text { matter }\end{array}$ & 10 & 4.7 & 12 & 14.3 & 8 & 6.9 & 5.4 & 4.4 & 4 \\
\hline Insect remains & 0 & 0 & 0 & 0 & 0 & 0 & 0 & 0 & 0 \\
\hline Fungal remains & 0 & 0 & 0 & 0.9 & 0 & 0 & 0 & 2 & 0 \\
\hline Recent excrements & 0 & 0 & 0 & 2.7 & 0 & 0 & 0 & 3 & 2 \\
\hline Ancient excrements & 1 & 0 & 2 & 0 & 0.9 & 0 & 0 & 0 & 0 \\
\hline Voids & 18 & 18.9 & 21 & 29.5 & 20.5 & 42.6 & 35.9 & 33.4 & 31.7 \\
\hline Free mineral grains & 1 & 0.9 & 1 & 0 & 0 & 2 & 50 & 2.2 & 1 \\
\hline $\begin{array}{l}\text { Course mineral components in } \\
\text { aggregates }\end{array}$ & 18 & 11.3 & 16 & 24.1 & 32.1 & 5.9 & 0 & 5.5 & 5 \\
\hline $\begin{array}{l}\text { Fine mineral components in } \\
\text { aggregates }\end{array}$ & 47 & 64.2 & 48 & 24.1 & 36.6 & 42.6 & 8.7 & 48.5 & 56.4 \\
\hline
\end{tabular}

The presence of ancient excrements and the absence of the contemporary earthworm activity features in the industrial land use may explain the disappearance of earthworms from the A horizon due to metal contamination (Table 2) [48, 49]. Earthworm might have been affected by the presence of $\mathrm{Cd}$ and $\mathrm{Zn}$ mainly complexes with the SOM (Figure 4). Earthworms are known to ingest SOM together with inorganic materials leading to decreased biodiversity and the functionality of the soil in these environmental conditions. 
TABLE 6: Concentrations ( $\mathrm{mg} \mathrm{kg}^{-1}$ ) of metals in tissues of different plant collected in soils under various land uses in Cartagena (SE Spain).

\begin{tabular}{|c|c|c|c|c|c|c|}
\hline & & ite & $\begin{array}{c}\text { Urban site } \\
\text { Cunodon dactvlon }\end{array}$ & & te & $\begin{array}{c}\text { Agrarian site } \\
\text { Malva parviflora }\end{array}$ \\
\hline & Leafs & Stalk & Leafs & Stalks & Roots & Stalks \\
\hline $\mathrm{Fe}$ & 577 & 246 & 5199 & 773 & 788 & 1638 \\
\hline $\mathrm{Mn}$ & 148 & 104 & 166 & 27 & 38 & 65 \\
\hline $\mathrm{Zn}$ & 918 & 372 & 391 & 129 & 65 & 196 \\
\hline $\mathrm{Cu}$ & 25 & 14 & 36 & 11 & 12 & 13 \\
\hline $\mathrm{Pb}$ & 28 & 10 & 73 & n.d & n.d. & n.d. \\
\hline $\mathrm{Cd}$ & 3.2 & 1.4 & n.d & n.d & n.d. & n.d. \\
\hline
\end{tabular}

n.d.: not detected.

TABLE 7: Concentrations ( $\mathrm{mg} \mathrm{kg}^{-1}$ ) of potential toxic metals for each solid phase and soil use.

\begin{tabular}{|c|c|c|c|c|c|c|c|c|c|c|}
\hline \multirow[b]{2}{*}{ Metal } & \multirow[b]{2}{*}{ Solid phase } & \multicolumn{3}{|c|}{ Industral } & \multicolumn{2}{|c|}{ Urban } & \multicolumn{2}{|c|}{ Natural } & \multicolumn{2}{|c|}{ Agricultural } \\
\hline & & A & $\mathrm{C} 1$ & $\mathrm{C} 2$ & A & $\mathrm{C} 1$ & A & $\mathrm{C} 1$ & $\mathrm{~A}$ & $\mathrm{C} 2$ \\
\hline \multirow{7}{*}{$\mathrm{Fe}$} & Exchangeables & 10.52 & 6.25 & 4.02 & 0.85 & 1.51 & 0.89 & 0.75 & 0.45 & 0.35 \\
\hline & Carbonates & 137 & 108 & 82.8 & 52.7 & 199 & 78.3 & 91.3 & 75.9 & 67.4 \\
\hline & Oxidizable & 1004 & 309 & 1289 & 661 & 956 & 227 & 217 & 507 & 520 \\
\hline & Reducible/residuals & 18574 & 20548 & 18745 & 24587 & 26458 & 15478 & 11985 & 26478 & 25487 \\
\hline & Sum & 19726 & 20971 & 20121 & 25301 & 27614 & 15784 & 12294 & 27062 & 26075 \\
\hline & Total & 20831 & 19696 & 19195 & 26444 & 25080 & 14999 & 12554 & 24827 & 24520 \\
\hline & $\%$ recovery & 95 & 106 & 105 & 96 & 110 & 105 & 98 & 109 & 106 \\
\hline \multirow{7}{*}{$\mathrm{Mn}$} & Exchangeables & 4.12 & 2.58 & 3.98 & 5.49 & 3.58 & 0.75 & 0.54 & 2.27 & 2.84 \\
\hline & Carbonates & 111.2 & 39.9 & 80.1 & 147 & 99.9 & 105 & 88.8 & 99.0 & 95.2 \\
\hline & Oxidizable & 92.8 & 72.0 & 110 & 50.9 & 104 & 38.0 & 53.2 & 144 & 150 \\
\hline & Reducible/residuals & 146 & 225 & 80.5 & 313 & 202 & 129 & 80.5 & 252 & 213 \\
\hline & Sum & 354 & 340 & 274 & 516 & 409 & 273 & 223 & 497 & 461 \\
\hline & Total & 338 & 319 & 244 & 449 & 396 & 283 & 221 & 450 & 444 \\
\hline & $\%$ recovery & 105 & 106 & 112 & 115 & 103 & 96 & 101 & 110 & 104 \\
\hline \multirow{7}{*}{$\mathrm{Zn}$} & Exchangeables & 5.2 & 1.35 & 5.93 & 3.02 & 0.98 & 0.35 & 0.84 & 0.51 & 0.47 \\
\hline & Carbonates & 391 & 10.68 & 7.82 & 185 & 37.4 & 58.6 & 66.7 & 98.8 & 93.7 \\
\hline & Oxidizable & 411 & 8.98 & 6.71 & 99.2 & 46.6 & 27.3 & 5.12 & 87.5 & 90.9 \\
\hline & Reducible/residuals & 266 & 902 & 52.7 & 266 & 70.2 & 155 & 90.4 & 191 & 121 \\
\hline & Sum & 1072 & 923 & 73.1 & 553 & 155 & 241 & 163 & 377 & 306 \\
\hline & Total & 1002 & 796 & 65 & 523 & 163 & 212 & 143 & 342 & 331 \\
\hline & $\%$ recovery & 107 & 116 & 112 & 106 & 95 & 114 & 114 & 110 & 92 \\
\hline \multirow{7}{*}{$\mathrm{Cu}$} & Exchangeables & nd & nd & nd & 1.4 & 0.93 & 0.77 & nd & 0.51 & nd \\
\hline & Carbonates & 14.6 & 7.97 & 6.16 & 21.3 & 14.7 & 5.94 & 3.83 & 2.17 & nd \\
\hline & Oxidizable & 6.21 & 3.31 & 2.57 & 17.6 & 13.6 & 1.79 & 1.52 & 9.17 & 9.75 \\
\hline & Reducible/residuals & 7.29 & 8.32 & 11.2 & 15.1 & 25.6 & 9.69 & 10.5 & 15.7 & 12.5 \\
\hline & Sum & 30.6 & 18.6 & 19.9 & 55.5 & 54.9 & 18.1 & 15.8 & 27.6 & 22.2 \\
\hline & Total & 28.1 & 19.6 & 17.1 & 48 & 46.9 & 15.1 & 13.9 & 23.6 & 17.9 \\
\hline & $\%$ recovery & 109 & 95 & 117 & 116 & 117 & 120 & 114 & 117 & 124 \\
\hline \multirow{7}{*}{$\mathrm{Pb}$} & Exchangeables & nd & nd & nd & nd & nd & nd & nd & nd & nd \\
\hline & Carbonates & 10.1 & 15.18 & 3.54 & 326 & 272 & 112 & 76.6 & 57.8 & 25.6 \\
\hline & Oxidizable & 4.64 & 5.25 & 1.51 & 29.6 & 15.5 & 20.2 & 20.5 & 26.3 & 17.0 \\
\hline & Reducible/residuals & 50.2 & 90.2 & 5.21 & 125 & 135 & 135 & 102 & 65.8 & 68.2 \\
\hline & Sum & 64.9 & 110 & 10.26 & 481 & 423 & 268 & 199 & 150 & 111 \\
\hline & Total & 58.2 & 103 & 8.5 & 411 & 400 & 248 & 179 & 128 & 88.1 \\
\hline & $\%$ recovery & 112 & 107 & 121 & 117 & 106 & 108 & 111 & 117 & 127 \\
\hline
\end{tabular}

n.d.: not detected. 


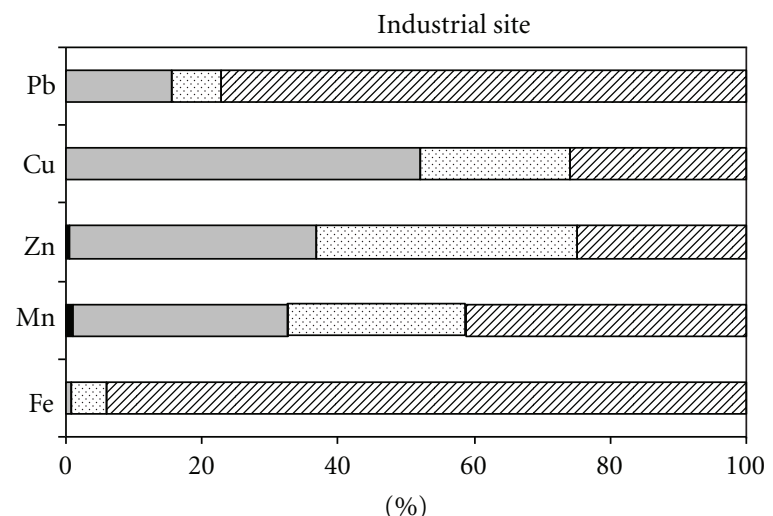

(a)

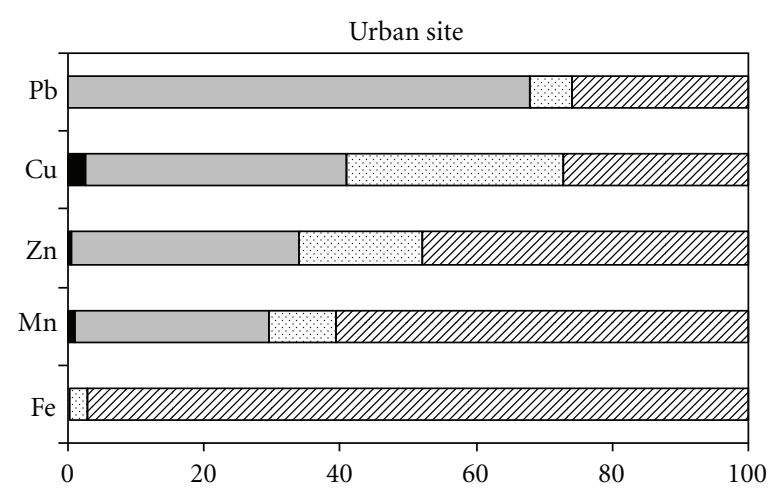

(\%)

$\mathrm{MgCl}$ extractable Oxidizable

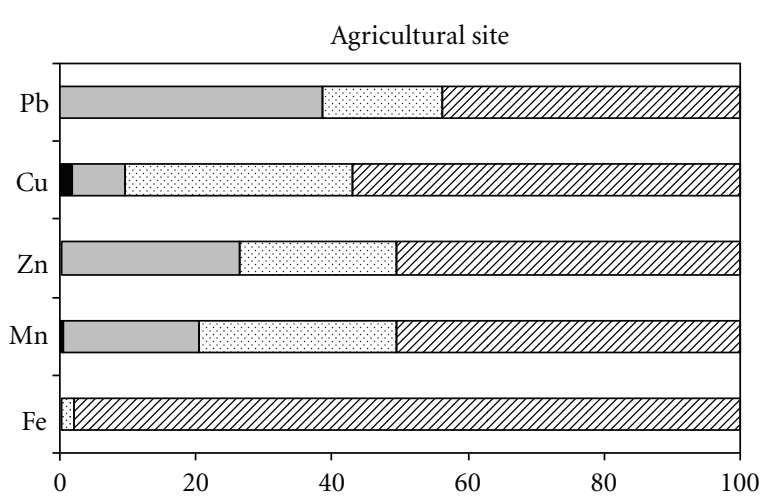

(\%)

(b)

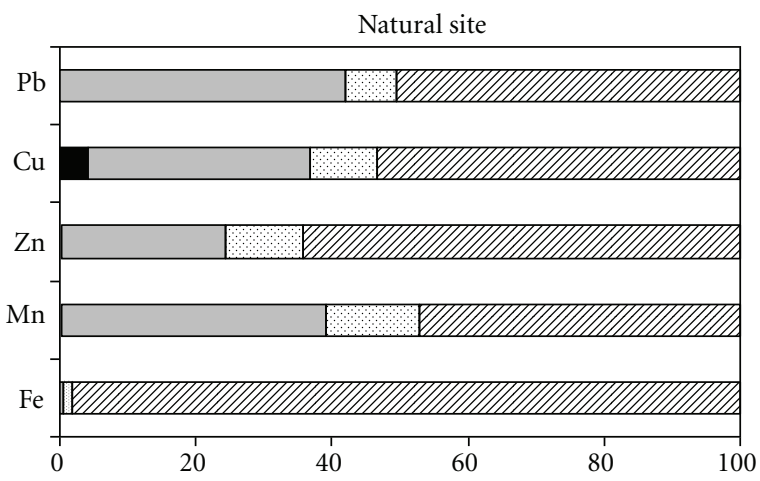

$(\%)$

$\mathrm{MgCl}$ extractable Oxidizable
NaOAc extractable

$\square$ Reducible/residual

(c)

(d)

FIGURe 4: Partitioning of potentially toxic metals in different fractions from the A horizons of soils under various land uses in Cartagena (SE Spain).

Large concentrations of $\mathrm{Zn}$ are in oxidisable phases such as organomineral complexes and mineral sulphides [12].

The presence of slightly and moderately decomposed SOM in the A horizon of the industrial site (Table 5 and Figure 3(e)) shows the low actual faunal activity that supports the previous hypothesis. In addition, high concentrations of $\mathrm{Zn}$ and $\mathrm{Cd}$ in plant tissues (Table 6) likely produce toxicity for soil micro fauna and prevent SOM decomposition. The aggregates of decomposed SOM in the A horizon are probably relict features inherited from a former soil system with abundant earthworm population. These features are most probably fossilized aggregates with an excremental fabric composed of organic particles and plasma and mineral clay and silt particles.

Abundant and intensively decomposed litter fragments $(12 \%)$ are observed in the $\mathrm{C} 2$ horizon of the industrial site, probably a relict from a former soil system with earthworm activity due to the occurrence of coarse and fine mineral components in the fabric of these aggregates. However, few but observables contemporary activities of fungi are identified in this horizon (Figure 3(f)) likely due to the migration of these microorganisms to this horizon because of its low pseudototal metals concentration.

\section{Conclusion}

Urban and natural profiles are contaminated with $\mathrm{Pb}, \mathrm{Cd}$, and $\mathrm{Zn}$, where the likely main sources are emissions from intense vehicular traffic, abrasion of tires and brakes in urban sites, and deposition of particles with PTMs transported by the wind for natural land use. The contamination of $\mathrm{Cd}$ and high level of $\mathrm{Zn}$ in the agricultural areas is likely due to the incorporation of sludge and atmospheric depositions from a nearby $\mathrm{Zn}$ producing industry. Although industrial profile is not considered contaminated, the highest $\mathrm{Zn}$ and $\mathrm{Cd}$ concentrations are observed in this site may have originated from and old fertilizer plant and a zinc producing industry.

Distribution of organic and inorganic components in the soil horizons from the four land uses was variable indicating different soil properties and microbiological activities. However, faunal activity is observed in all soil horizons, except the surface soil horizon under industrial land use where ancient SOM remains are only recognized 
due to elevated concentrations of $\mathrm{Pb}$ and $\mathrm{Zn}$ and high accumulation in SOM. High metals reduce biodiversity and the decrease functionality of the soil system in industrial sites. Conversely, the presence of active fauna in natural, urban, and agricultural land use show that pseudototal concentration of PTMs in soils is not a good indicator to predict fauna activity compared to the partitioning of metals to various solid phases. For example, carbonates and Fe/Mn oxides are an important sink or storage to reduce toxicity of metals in the study areas. In addition, external inputs to the soil such as organic and inorganic fertilizers can reduce the toxic effects of metals and enhance the faunal activity.

We propose that the toxic effects of PTMs in the soil faunal activity can be effectively evaluated when metal fractionation obtained by the sequential chemical extraction procedures is combined with direct observations of faunal activity using micromorphological techniques.

\section{Acknowledgments}

The authors would like to thank "Fundación Séneca" of "Comunidad Autónoma de Murcia" and the Natural Sciences and Engineering Research Council and the Canada Research Chair program (Canada) for financial support to undertake this study.

\section{References}

[1] J. Chronopoulos, C. Haidouti, A. Chronopoulou-Sereli, and I. Massas, "Variations in plant and soil lead and cadmium content in urban parks in Athens, Greece," Science of the Total Environment, vol. 196, no. 1, pp. 91-98, 1997.

[2] D. S. Manta, M. Angelone, A. Bellanca, R. Neri, and M. Sprovieri, "Heavy metals in urban soils: a case study from the city of Palermo (Sicily), Italy," Science of the Total Environment, vol. 300, no. 1-3, pp. 229-243, 2002.

[3] P. K. Govil, G. L. N. Reddy, and A. K. Krishna, "Contamination of soil due to heavy metals in the Patancheru industrial development area, Andhra Pradesh, India," Environmental Geology, vol. 41, no. 3-4, pp. 461-469, 2001.

[4] O. Abollino, M. Aceto, M. Malandrino, E. Mentasti, C. Sarzanini, and R. Barberis, "Distribution and mobility of metals in contaminated sites. Chemometric investigation of pollutant profiles," Environmental Pollution, vol. 119, no. 2, pp. 177-193, 2002.

[5] H. E. Gäbler and J. Schneider, "Assessment of heavy-metal contamination of floodplain soils due to mining and mineral processing in the Harz Mountains, Germany," Environmental Geology, vol. 39, no. 7, pp. 774-782, 2000.

[6] A. Navas and H. Lindhorfer, "Geochemical speciation of heavy metals in semiarid soils of the central Ebro Valley (Spain)," Environment International, vol. 29, no. 1, pp. 61-68, 2003.

[7] S. Norra, M. Lanka-Panditha, U. Kramar, and D. Stüben, "Mineralogical and geochemical patterns of urban surface soils, the example of Pforzheim, Germany," Applied Geochemistry, vol. 21, no. 12, pp. 2064-2081, 2006.

[8] K. D. Van Den Hout, D. J. Bakker, J. J. M. Berdowski et al., "The impact of atmospheric deposition of non-acidifying substances on the quality of European forest soils and the North Sea," Water, Air, and Soil Pollution, vol. 109, no. 1-4, pp. 357-396, 1999.
[9] A. Colgan, P. K. Hankard, D. J. Spurgeon, C. Svendsen, R. A. Wadsworth, and J. M. Weeks, "Closing the loop: a spatial analysis to link observed environmental damage to predicted heavy metal emissions," Environmental Toxicology and Chemistry, vol. 22, no. 5, pp. 970-976, 2003.

[10] F. A. Nicholson, S. R. Smith, B. J. Alloway, C. Carlton-Smith, and B. J. Chambers, "An inventory of heavy metals inputs to agricultural soils in England and Wales," Science of the Total Environment, vol. 311, no. 1-3, pp. 205-219, 2003.

[11] J. A. Rodríguez Martín, M. L. Arias, and J. M. Grau Corbí, "Heavy metals contents in agricultural topsoils in the Ebro basin (Spain). Application of the multivariate geoestatistical methods to study spatial variations," Environmental Pollution, vol. 144, no. 3, pp. 1001-1012, 2006.

[12] R. Moral, R. J. Gilkes, and M. M. Jordán, "Distribution of heavy metals in calcareous and non-calcareous soils in Spain," Water, Air, and Soil Pollution, vol. 162, no. 1-4, pp. 127-142, 2005.

[13] A. Tessier, P. G. C. Campbell, and M. Bisson, "Sequential extraction procedure for the speciation of particulate trace metals," Analytical Chemistry, vol. 51, no. 7, pp. 844-851, 1979.

[14] Z. S. Ahnstrom and D. R. Parker, "Development and assessment of a sequential extraction procedure for the fractionation of soil cadmium," Soil Science Society of America Journal, vol. 63, no. 6, pp. 1650-1658, 1999.

[15] H. Khademi and A. R. Mermut, "Micromorphology and classification of Argids and associated gypsiferous Aridisols from central Iran," Catena, vol. 54, no. 3, pp. 439-455, 2003.

[16] F. Khormali, A. Abtahi, and G. Stoops, "Micromorphology of calcitic features in highly calcareous soils of Fars Province, Southern Iran,” Geoderma, vol. 132, no. 1-2, pp. 31-46, 2006.

[17] P. Bullock, N. Fedoroff, A. Jongerius, G. Stoops, T. Tursma, and U. Babel, Handbook for Soil Thin Section Description, Waine Research Publications, Wolverhampton, UK, 1985.

[18] E. A. Fitzpatrick, Soil Microscopy and Micromorphology, Wiley, Chichester, UK, 1993.

[19] G. García, E. Lorente, and A. Faz, "Elemental characterization of contaminated soils and sediments from the industrial area of "EL Hondon" (Cartagena, SE Spain)," in Sustainable Use and Management of Soil in Arid and Semiarid Regions, A. Faz, R. Ortiz, and A. R. Mermut, Eds., vol. 2, pp. 416-417, 2002.

[20] J. A. Acosta, S. Martínez-Martinez, A. Faz, G. García, J. M. Van Mourik, and J. M. Verstraten, "Spatial distribution of heavy metals in the soils of cartagena (SE Spain): the influence of the use of soils," Catena, vol. 1, pp. 407-420, 2005.

[21] A. Faz, G. García, R. Arnaldos, and L. Carrasco, "Reclamation of polypolluted soils from the industrial area of Cartagena. (SE Spain): phytoaccumulation and phytostabilization," in Proceedings of the 1st European Bioremediation conference, Polytechnic University, Crete, Greece, 2001.

[22] FAO-ISRIC, Guidelines for Soil Description, F. A. O., Roma, Italy, 4th edition, 2006.

[23] WRB, World Reference Base for Soil Resources. A Framework for International Classification, Correlation and Communication, $\mathrm{F}$. A. O., Roma, Italy, 2006.

[24] M. Peech, "Hidrogen-ion activity," in Methods of Soil Analysis, C. A. Black, Ed., vol. 2, pp. 914-916, American Society of Agronomy, Madison, Wis, USA, 1965.

[25] Wesemael, "Organic carbon determination," in Compilation of Procedures for Practical Classes in Soil Chemistry, L. Hoitinga and I. van Voorthuijsen, Eds., Fysisch Geografisch \& Bodemkundig Laboratorium, Universiteit van Amsterdam, The Netherlands, 1995. 
[26] L. E. Allison, "Organic carbon by reduction of chromic acid," Soil Science, vol. 40, pp. 311-320, 1935.

[27] Rhoades, in Compilation of Procedures for Practical Classes in Soil Chemistry, L. Hoitinga and I. van Voorthuijsen, Eds., Fysisch Geografisch \& Bodemkundig Laboratorium, Universiteit van Amsterdam, The Netherlands, 1997.

[28] M. Bettinelli, G. M. Beone, S. Spezia, and C. Baffi, "Determination of heavy metals in soils and sediments by microwaveassisted digestion and inductively coupled plasma optical emission spectrometry analysis," Analytica Chimica Acta, vol. 424, no. 2, pp. 289-296, 2000.

[29] W. S. Bowman, G. H. Faye, R. Sutarno, J. A. McKeague, and H. Kodama, "Soil samples SO-1, SO-2, SO-3 and SO4-certified reference materials," CANMET Report 79-3, CANMET Mining and Mineral Sciences Laboratories, Ottawa, Canada, 1979.

[30] J. M. Van Mourik, "The use of micromorphology in soil pollen analysis the interpretation of the pollen content of slope deposits in Galicia, Spain," Catena, vol. 35, no. 2-4, pp. 239257, 1999.

[31] J. M. Van Mourik, "Pollen and spores, preservation in ecological settings," in Palaeobiology II, E. G. Briggs and P. R. Crowther, Eds., pp. 315-318, Blackwell Science, 2001.

[32] M. J. Martínez-Sánchez and C. Pérez-Sirvent, Niveles de Fondo y Niveles Genéricos de Referencia de Metales Pesados en Suelos de la Región de Murcia, Murcia, Spain, 2007.

[33] M. Romic and D. Romic, "Heavy metals distribution in agricultural topsoils in urban area," Environmental Geology, vol. 43, no. 7, pp. 795-805, 2003.

[34] M. J. Norusis, SPSS for Windows Base System User's Guide Release 6.0, SPSS, Chicago, Ill, USA, 1993.

[35] E. A. FizPatrick, Soils: Their Formation, Clasification and Distribution, Longman, New York, NY, USA, 1980.

[36] T. P. Urbano, Tratado de Fitotecnia General, Mundi Prensa, Madrid, Spain, 2nd edition, 1995.

[37] J. Porta, M. López, and C. Roquero, Edafología Para la Agricultura y el Medio Ambiente, Mundi Prensa, Madrid, Spain, 2nd edition, 1999.

[38] D.C. Adriano, "Zinc," in Trace Elements in the Terrestrial Environment, D.C. Adriano, Ed., pp. 421-469, Springer, New York, NY, USA, 1986.

[39] N. L. Ward, "Multielement contamination of British motorway environments," in Proceedings of the International Conference on Heavy Metals in the Environment, J. P. Vernet, Ed., vol. 2, CEP Consultants, Geneva, Switzerland, September 1989.

[40] M. Imperato, P. Adamo, D. Naimo, M. Arienzo, D. Stanzione, and P. Violante, "Spacial distribution of heavy metals in urban soils of NaplesCity (Italy)," Environmental Pollution, vol. 124, pp. 247-256, 2003.

[41] J. J. Capel Molina, "El clima del territorio de cartagena," in Historia de Cartagena, F. P Pérez, C. G Piñarés, P. G Reverte, F. L Hernández, and A. Alcolea, Eds., pp. 171-192, 1986.

[42] M. Hutton and C. Symon, "The quantities of cadmium, lead, mercury and arsenic entering the U.K. environment from human activities," Science of the Total Environment, vol. 57, pp. 129-150, 1986.

[43] T. Kunito, K. Saeki, H. Oyaizu, and S. Matsumoto, "Influences of copper forms on the toxicity to microorganisms in soils," Ecotoxicology and Environmental Safety, vol. 44, no. 2, pp. 174$181,1999$.

[44] Y. Wang, J. Shi, H. Wang, Q. Lin, X. Chen, and Y. Chen, "The influence of soil heavy metals pollution on soil microbial biomass, enzyme activity, and community composition near a copper smelter," Ecotoxicology and Environmental Safety, vol. 67, no. 1, pp. 75-81, 2007.

[45] G. S. Francis and P. M. Fraser, "The effects of three earthworm species on soil macroporosity and hydraulic conductivity," Applied Soil Ecology, vol. 10, no. 1-2, pp. 11-19, 1998.

[46] M. M. Lasat, "Phytoextraction of toxic metals: a review of biological mechanisms," Journal of Environmental Quality, vol. 31, no. 1, pp. 109-120, 2002.

[47] S. P. McGrath, F. J. Zhao, and E. Lombi, "Plant and rhizosphere processes involved in phytoremediation of metalcontaminated soils," Plant and Soil, vol. 232, no. 1-2, pp. 207214, 2001.

[48] E. F. Dijkstra, J. J. Boon, and J. M. Van Mourik, "Analytical pyrolysis of a soil profile under Scots pine," European Journal of Soil Science, vol. 49, no. 2, pp. 295-304, 1998.

[49] E. F. Dijkstra and J. M. Van Mourik, "Reconstruction of recent forest dynamics based on pollen analysis and micro morphological studies of young acid forest soils under Scots pine plantations," Acta Botanica Neerlandica, vol. 45, no. 3, pp. 393-410, 1996. 

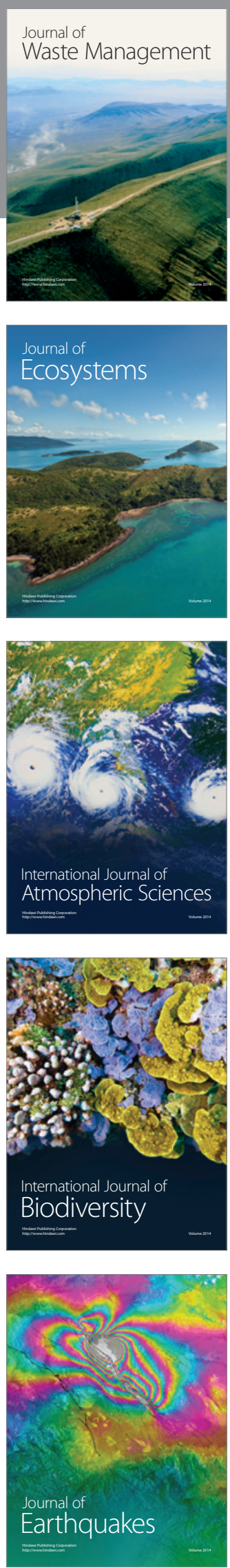
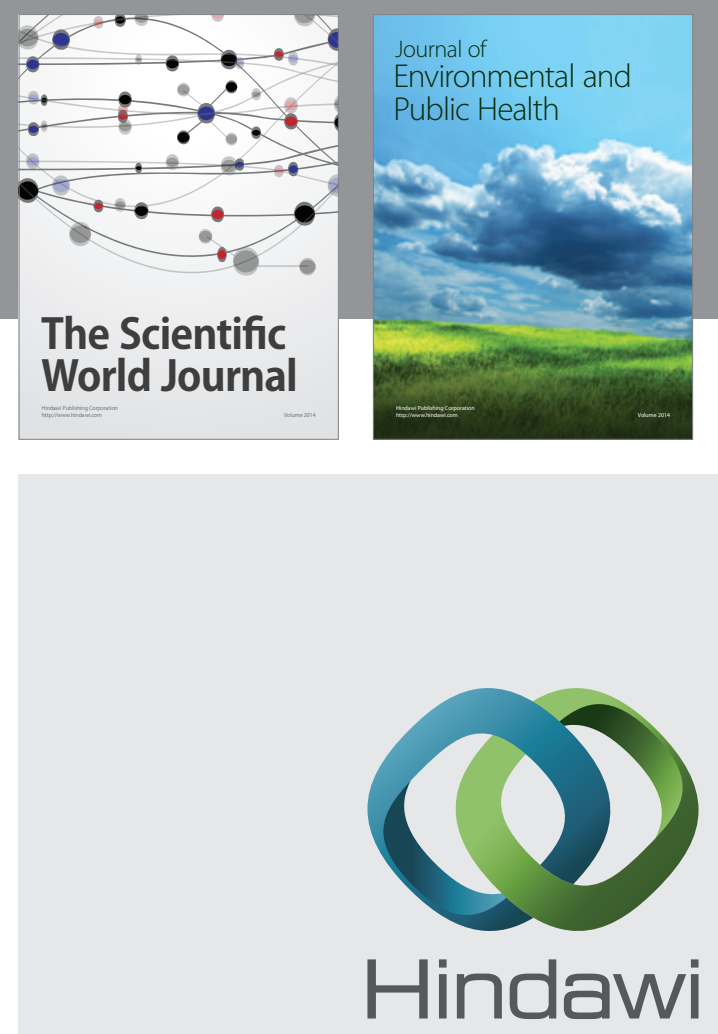

Submit your manuscripts at

http://www.hindawi.com
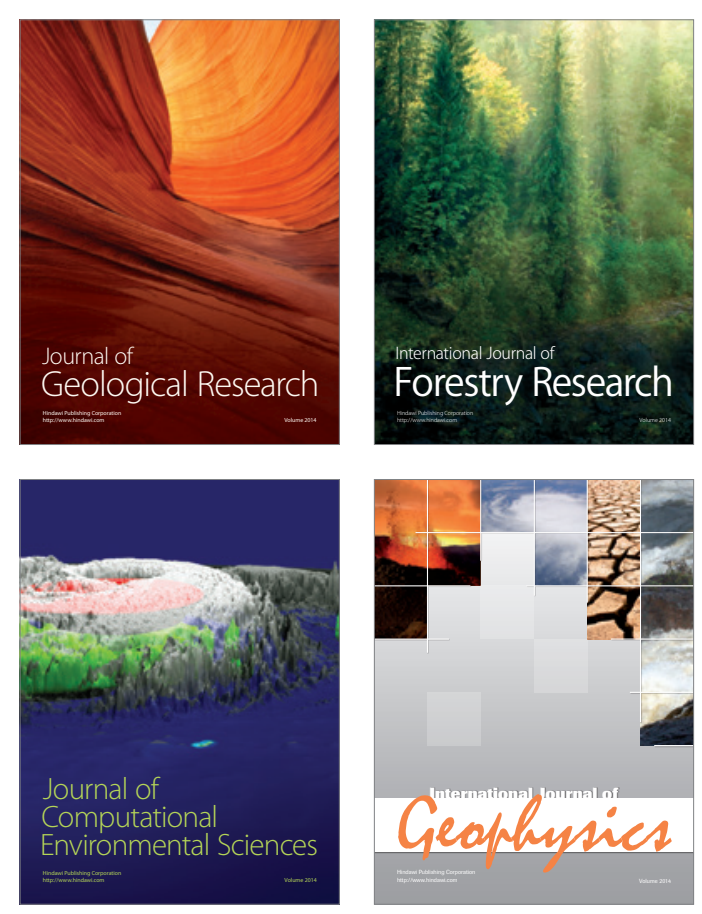
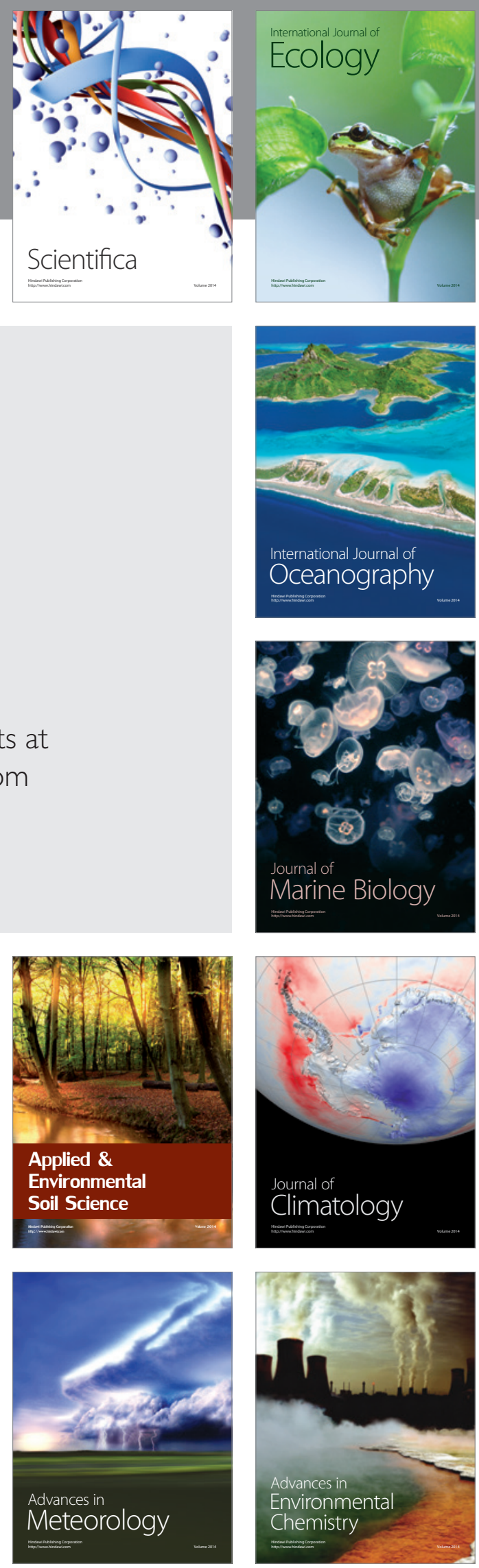